Int. J. Odontostomat., 11(1):89-94, 2017.

\title{
Cone Beam Computed Tomography in the Diagnosis of Dens Invaginatus: Case Report
}

\author{
Tomografía Computarizada de Haz Cónico en el Diagnóstico \\ de Diente Invaginado: Presentación De Un Caso
}

\begin{abstract}
Priscila Dias Peyneau'; Eliana Dantas da Costa1; Francielle Silvestre Verner²; Deborah Queiroz de Freitas ${ }^{3}$; Solange Maria Almeida ${ }^{3}$ \& Glaucia Maria Bovi Ambrosano ${ }^{4}$
\end{abstract}

PEYNEAU, P. D.; DA COSTA, E. D.; VERNER, F. S.; DE FREITAS, D. Q.; ALMEIDA, S. M. \& AMBROSANO, G. M. B. Cone beam computed tomography in the diagnosis of dens invaginatus: Case report. Int. J. Odontostomat., 11(1):89-94, 2017.

ABSTRACT: The aim of this report is to present a case of dens invaginatus asymptomatic discovered after exam cone beam computed tomography. A 20-year-old patient attended the clinic Radiology to perform tomography to fracture research at the root of the tooth 15 . However, the examination was observed the presence of a conoid supernumerary tooth between the tooth located roots 11 and 12, which had a hyperdense line to the apex of the root, representing the invagination of the enamel, dens invaginatus feature. It was also observed extensive hypodense image in the periapical region, with areas of external resorption both in supernumerary tooth as we II as the roots of teeth 11 and 12 . The treatment consisted of surgery for dens invaginatus extraction. The dentists should be aware of the imaginological characteristics of the anomalies that can affect the teeth/jaws, which can be discovered in tests for routine imaging and proper conduct for the treatment of patients.

KEY WORDS: dens in dente, cone-beam computed tomography, tooth abnormalities.

\section{INTRODUCTION}

Dens invaginatus (DI), also known as dens in dente, dilated composite odontoma, invaginated odontoma, dilated gestant odontoma, tooth inclusion or dentoid in dente (Hülsmann, 1997; Durack \& Patel, 2011; Pradeep et al., 2012), is a developmental tooth anomaly characterized by invagination of the enamel organ into the dental papilla prior to calcification of the dental tissues (Jaya et al., 2013; Kfir et al., 2013; Kaya-Büyükbayram et al., 2014; Muppa et al., 2014; Teixeidó et al., 2014; Capar et al., 2015; Nosrat \& Schneider, 2015).

This can occur both in the crown as the root and may involve the pulp chamber or root canal, resulting in deformity in their morphology (Mishra et al., 2012). According to the literature, the frequency varies from 0.04 $\%$ to $10 \%$ (Hovland, 1977; Hülsmann; Pradeep et al.;
Jaya et al.; Brooks \& Ribera, 2014; Ceyhanli et al., 2014; Kaya-Büyükbayram et al.; Teixeidó et al.; Zubizarreta Macho et al., 2015), predominating in female (3:1) (Alani \& Bishop, 2008; Mishra et al.), affecting either the deciduous or the permanent dentition (Alani \& Bishop; Jaya et al.). The most affected permanent teeth are the maxillary lateral incisors (Oehlers, 1957; Cohenca \& Berg, 2013; Jaya et al.; Kfir et al.; Brooks \& Ribera; Ceyhanli et al.; Kaya-Büyükbayram et al., Muppa et al.; Vier-Pelisser et al., 2014; Capar et al.; Zubizarreta Macho et al.; Nosrat \& Schneider), frequently bilaterally (43 \%) (Hülsmann; Durack \& Patel; Mishra et al.; Pradeep et al.; Cohenca \& Berg; Jaya et al.; Zubizarreta Macho et al.), followed by central incisors, including supernumerary teeth, maxillary cuspids, mandibular incisors, and mandibular premolars affecting the molars

1 Division of Oral Radiology, Department of Oral Diagnosis, Piracicaba Dental School, State University of Campinas, Piracicaba, SP, Brazil. 2 Department of Dentistry, Division of Oral Radiology, Federal University of Juiz de Fora, Governador Valadares Campus, Governador Valadares, MG, Brazil.

${ }^{3}$ Professor of Division of Oral Radiology, Department of Oral Diagnosis, Piracicaba Dental School, State University of Campinas, Piracicaba, SP, Brazil.

${ }^{4}$ Professor of Biostatistics, Department of Social Dentistry, Piracicaba Dental School, State University of Campinas, Piracicaba, SP, Brazil. 
rarely (Oehlers; Cohenca \& Berg; Jaya et al.), rarely affecting the molars (Bansal \& Pratap, 2010; Matsusue et al., 2011).

Although the etiology of $\mathrm{DI}$ being indefinite (Alani \& Bishop; Teixeidó et al.), several hypotheses are suggested, such as external forces on the tooth bud during development, such as nearby tooth buds, infection, trauma, focal growth acceleration, and retardation of the tooth bud, is also associated with genetic disorders (Pradeep et al.; Kfir et al.; KayaBüyükbayram et al.; Muppa et al.; Teixeidó et al.; Capar et al.; Zubizarreta Macho et al.).

The DI may exhibit absence of clinical symptoms (Muppa et al.), crown with normal morphology (Durack \& Patel), as well as the presence of a deep blind foramen coated by a fragile hypomineralized enamel, resulting in an external communication via with the dental pulp (Kfir et al.; Muppa et al.). As this area is difficult to clean and might be the first clinical sign indicating the presence of an invaginated tooth (Vier-Pelisser et al., 2014). The adverse effects clinically including increased risk of caries, with subsequent pulp necrosis and evolution to apical pathosis, and periodontal inflammation (Patel et al., 2010; Vier-Pelisser et al., 2012; Kfir et al.).

Three types of invaginations have been suggested, irrespective of the teeth in which they occur. The most clinically relevant and is by far the most commonly used in clinical studies, case reports and case series, possibly because of its simple nomenclature and ease of application (Alani \& Bishop; Jaya et al.), is the classification system proposed by Oehlers.

The cases are grouped in three categories, according to the depth of the invagination and the existence of communication with the pulp tissue or periodontal ligament. The type $I$ is an enamel lined minor invagination occurring within the confines of the tooth crown not extending beyond the cementoenamel junction; in type II, the invagination extends apically beyond the cementoenamel junction, but remains confined within it as a blind sac and it may or may not communicate with the dental pulp; in type III, the invagination penetrates through the root, perforating the apical area and having a second foramen in the apical or periodontal area, but there is no immediate communication with the pulp (Oehlers; Kfir et al.; Ceyhanli et al.; Kaya-Büyükbayram et al.; Vier-Pelisser et al., 2014; Capar et al.; Zubizarreta Macho et al.; Nosrat \& Schneider).
The radiographic aspect of the DI depends on the severity of the invagination (Patel et al., 2010; Durak \& Patel, 2011). Radiographically, the affected tooth shows an infolding of the enamel and dentin, which may extend deep into the root and sometimes reach the apex (Jaya et al.). The defects may vary in size and shape, from a loop-like, pear-shaped or a slightly radiolucent structure to a severe form resembling a "tooth within a tooth" (also named dens-in-dent) (Neves et al., 2010).

Cone beam computed tomography (CBCT) is a contemporary radiological imaging modality overcoming various inherent limitations of conventional radiography (Jaya et al.). The tooth can be viewed at multiple planes, providing to the dentist a detailed image of the teeth anatomy (Teixeidó et al.). Endodontic applications of CBCT include the diagnosis of periapical lesions, more detailed visualization of root anatomy, elucidation of internal and external resorption, and detection of root fractures (Tyndall \& Rathore, 2008; Kaneko et al., 2011). CBCT also operates with a lower radiation dose as compared to multi-slice computed tomography (Tyndall \& Rathore; Durack \& Patel; Kaneko et al., 2011; Pradeep et al.; Jaya et al.; Kfir et al.; Teixeidó et al.) although higher than that of conventional dental radiography techniques (Kfir et al.; Capar et al.). This paper describes the use of CBCT as an effective diagnostic tool for the DI well as in the treatment planning.

\section{CASE REPORT}

A male patient 20 years old, attended the clinic Radiology to perform CBCT to research a root fracture in the tooth 15 after loss of the prosthetic crown, was reported pain percussion. The three-dimensional exam was done using i-CAT CBCT (Imaging Sciences, Hatfield, USA), operated at $120 \mathrm{kVp}, 5 \mathrm{~mA}, 14 \times 8 \mathrm{~cm}$ field of view (FOV), voxel 0.25 .

On the CBCT images, it was noted the presence of conoide supernumerary tooth located between the teeth 11 and 12 (Figs. 1 and 2). The supernumerary tooth had bulbous root associated an extended area of radiolucency adjacent to the root apex. It became evident that there was a DI with invagination extending nearly to the root apex. Observed still the presence of a hyperdense line until the tooth apex, representing the invagination of the enamel, and an extensive hypodense image in the periapical region 


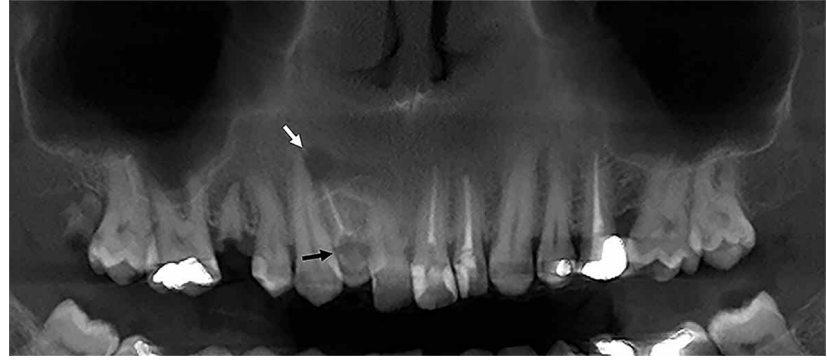

Fig. 1. Panoramic reconstruction of the maxilla. White arrow: osteolytic lesion adjacent to the root apex. Black arrow: Dens invaginatus.
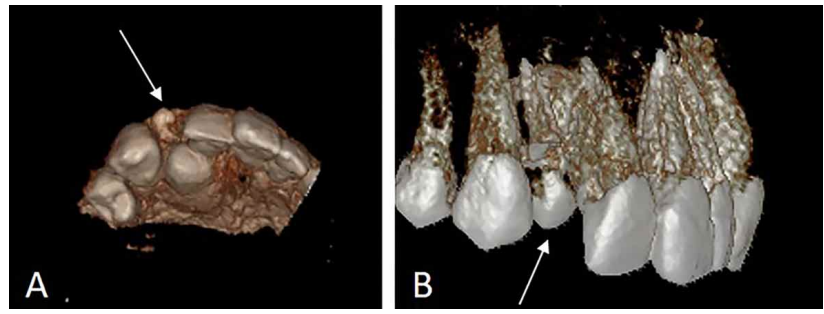

Fig. 2. Three-dimensional reconstruction showing the conoide supernumerary tooth (white arrow) located between the teeth 11 and 12. Oclusal view $(\mathrm{A})$ and vestibular view of the right side $(\mathrm{B})$.

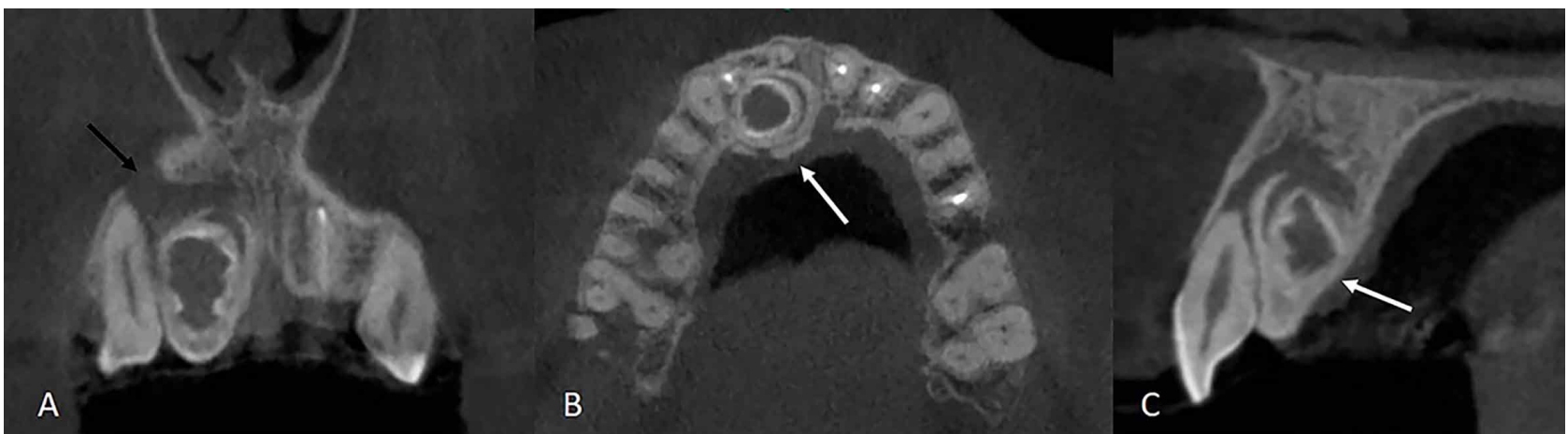

Fig. 3. Cone beam computed tomography images of the maxilla presentation of the case. A. Coronal section. Black arrow: osteolytic lesion. B. Axial section. C. Sagital section. White arrow: Dens invaginatus: Note the large space of the pulp and the emanel invagination.

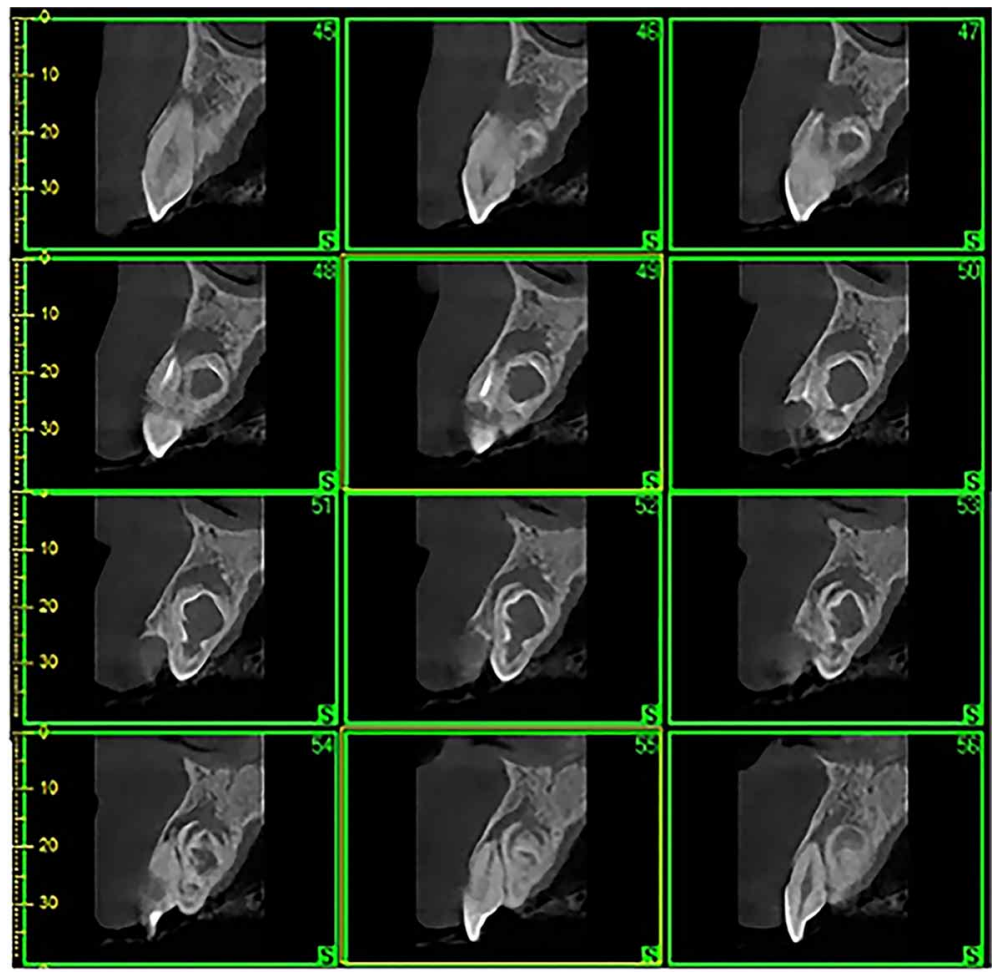

(Figs. 3 and 4). It was also noted the external root resorption of the supernumerary tooth in the medium and cervical areas of the root, and external root resorption of teeth 11 and 12 (Fig. 5).

A diagnosis for Oehlers' type III (16) of dens invaginatus was made. And then, the extraction of upper right maxillary supernumerary was planned. Since it is a severe anomaly and with extensive pulp involvement, it was suggested radiographic follow up of teeth 11 and 12.

Fig. 4. Cross-section: Note proximity of the DI with tooth 12 and osteolytic lesion. 


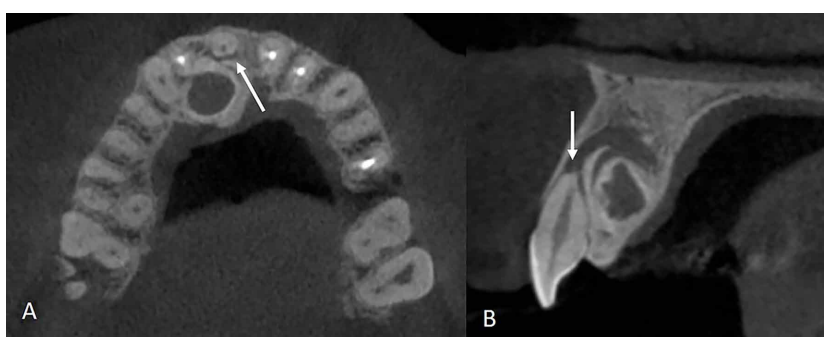

Fig. 5. A. Axial section: external root resorption of teeth 11. B. Sagital section: external root resorption of teeth 11 .

\section{DISCUSSION}

DI primarily occurs in permanent dentition; however, cases have been reported in supernumerary teeth, microdontia, macrodontia, hypodontia, oligodontia, taurodontism, fusion and germination (Hülsmann; Neves et al., 2010; Capar et al.; Zubizarreta Macho et al.). The maxillary teeth are more commonly affected than mandibular teeth (Bansal \& Pratap). DI commonly affects the maxillary lateral incisors (Hülsmann; Bansal \& Pratap; Mishra et al.). The present case involved a maxillary supernumerary tooth.

Regarding to the crown morphology of the teeth with DI, it may vary ranging from the most unusual and different shapes with a multitude of shapes and sizes (Neves et al.; Kfir et al.; Vier-Pelisser et al., 2014; Zubizarreta Macho et al.), such as a greater buccolingual diameter, grooves, slots, slight deformations, conical shape, plug shape, barrel shape or talon cusp shape (Neves et al.; Durack \& Patel; Kfir et al.; Zubizarreta Macho et al.). In the present case reported, the tooth presented with the conoid form.

In teeth affected by DI, the invagination of enamel organ and the presence of malformed or absent enamel cause the accumulation of debris, facilitating the fast progression of dental caries and subsequent involvement of the pulp, leading to periapical or periodontal abscess (Kaneko et al., 2011; Kallianpur et al., 2012; Ceyhanli et al.; Vier-Pelisser et al., 2014; Capar et al.). Thus, the dental problems in DI are mainly related to the degree of bacterial invasion along the enamel invagination (Narayana et al., 2012). In type III DI (Oehlers), as in the present case, any bacterial contamination present in the invagination can evolve into an inflammatory response through the periodontal tissues, leading to periapical pathology (Neves et al.; Nosrat \& Schneider).
Thus, early diagnosis is essential to avoid more complex treatments (Ceyhanli et al.; Capar et al.). The treatment options for DI include preventive sealing or filling of the invagination, surgical or nonsurgical root canal treatment, intentional replantation, and extraction (Bansal \& Pratap; Kaneko et al., 2011; Pradeep et al.; Jaya et al.; Kfir et al.; Brooks \& Ribera; Capar et al.; Zubizarreta Macho et al.). According to Vier-Pelisser et al., (2014) extraction is indicated in teeth with large anatomical irregularities, which precludes endodontic and supernumerary treatment. In the present case, the tooth affected by DI also showed severe invagination and extensive apical periodontitis, and, being a supernumerary, the extraction was conducted.

Still regarding to the DI identification, according to Teixeidó et al., despite conventional or digital periapical radiographs play an important role in the diagnosis, they can do not provide details regarding the type and extent of invagination. In the conventional radiographs, it is not always possible to determine with great precision the relationship between the invaginated portion of the tooth with the chamber and/or the root canals, since conventional radiography provides only one image in two dimensions (Patel et al.; Mishra et al.; Kfir et al.; Teixeidó et al.).

These limitations can be overcome with the use of CBCT (Pradeep et al.; Teixeidó et al. \& Capar et al.), which is an important tool in the diagnosing, treatment planning and monitoring of complex DI (Pradeep et al.; Ceyhanli et al.; Kaya-Büyükbayram et al.; Vier-Pelisser et al., 2014). As a three-dimensional images, CBCT has several other advantages over conventional radiography, like elimination of overlapping of anatomical structures, and management of various dental malformations and endodontics (Mishra et al.; Muppa et al.; Teixeidó et al.; Nosrat \& Schneider), allowing accurate visualization of internal and external anatomy of teeth affected by DI (Capar et al.; Nosrat \& Schneider) and associated tissues (Kaneko et al., 2011; Kfir et al.).

Despite the CBCT expose to a higher radiation dose compared to conventional radiographic examination, their use can be justified due to the risk / benefit ratio when there is a complex endodontic treatment of DI (Kfir et al.), since the conventional radiographs have limitations related to an accurate assessment of the severity of invagination (Durack \& Patel). 
Upon using CBCT, the presence of apical periodontitis in teeth affected by DI can be diagnosed earlier compared to the conventional radiographs, and show the real size of the lesion, providing accurate information about the slope of the roots and thickness of cortical bone (Vier-Pelisser et al., 2014). In addition, СВCT can help dentists in better understanding the complex morphology of the root canal of DI, providing an effective endodontic treatment (Nosrat \& Schneider).

In the study of the Mishra et al., as in this case, the tomographic images made it possible to observe an invagination which was communicating with the periodontal space, resulting in a large periapical lesion, which permitted us to classify the condition as type III DI. There was a bulbous root, but there was the presence of a single apical foramen. In this case, CBCT was essential in diagnosis of external root resorption in supernumerary teeth with $\mathrm{DI}$ as well as in teeth 11 and 12. This case shows how CBCT has accuracy in morphological changes in the teeth.

According to Zubizarreta Macho et al., the therapeutic prognosis of $\mathrm{DI}$ is related to the technical advances in Radiology. Thus, the use of CBC. This provided more information about the anatomy of these teeth, supporting the treatment planning.

\section{CONCLUSION}

DI is often an asymptomatic anomaly found at in imaging exams. However, in complex cases, the patient may report pain and present swelling face due to pulp and periapical involvement. Thus, in such cases, CBCT is an important exam for the diagnosis and planning treatment.

PEYNEAU, P. D.; DA COSTA, E. D.; VERNER, F. S.; DE FREITAS, D. Q.; ALMEIDA, S. M.; AMBROSANO, G. M. B. Tomografía computarizada de haz cónico en el diagnóstico de diente invaginado: presentación de un caso. Int. J. Odontostomat., 11(1):89-94, 2017.

RESUMEN: El objetivo de este trabajo fue presentar un caso de dens invaginatus asintomático descubierto en una tomografía computarizada de haz cónico. Un paciente de 20 años de edad acudió a la clínica radiológica para realizarse una tomografía producto una fractura radicular del diente 15. Sin embargo, en el exámen se observó la presencia de un diente supernumerario cónico localizado entre las raíces de los dientes 11 y 12, observando además una línea hiperdensa hacia el ápice de la raíz, que representa la invaginación del esmalte, característica propia de un dens invaginatus. También se observó un área hipodensa en la región periapical, con áreas de reabsorción externa tanto en el diente supernumerario como en las raíces de los dientes 11 y 12. El tratamiento consistió en cirugía de extracción del dens invaginatus. Los dentistas deben conocer las características imagenológicas de las anomalías que pueden afectar a los dientes, las cuales pueden ser descubiertas en exámenes de rutina y también el protocolo adecuado de tratamiento de éstas.

PALABRAS CLAVE: dens in dente, tomografía computarizada de haz cónico, anomalias dentarias.

\section{REFERENCES}

Alani, A. \& Bishop, K. Dens invaginatus. Part 1: classification, prevalence and aetiology. Int. Endod. J., 41(12):1123-36, 2008.

Bansal, M.; Singh, N. \& Singh, A. P. A rare presentation of dens in dente in the mandibular third molar with extra oral sinus. J. Oral Maxillofac. Pathol., 14(2):80-2, 2010.

Brooks, J. K. \& Ribera, M. J. Successful nonsurgical endodontic outcome of a severely affected permanent maxillary canine with dens invaginatus Oehlers type 3. J. Endod., 40(10):1702-7, 2014

Capar, I. D.; Ertas, H.; Arslan, H. \& Tarim Ertas, E. A retrospective comparative study of cone-beam computed tomography versus rendered panoramic images in identifying the presence, types, and characteristics of dens invaginatus in a Turkish population. J. Endod., 41(4):473-8, 2015.

Ceyhanli, K. T.; Çelik, D.; Altintas, S. H.; Tasdemir, T. \& Sezgin O. S. Conservative treatment and follow-up of type III dens invaginatus using cone beam computed tomography. J. Oral Sci., 56:30710, 2014

Cohenca, N. \& Berg, J. Diagnosis and conservative treatment of dens invaginatus type III using cone beam computed tomography: two case reports. Pediatr. Dent., 35(1):E33-7, 2013.

Durack, C. \& Patel S. The use of cone beam computed tomography in the management of dens invaginatus affecting a strategic tooth in a patient affected by hypodontia: a case report. Int. Endod. J., 44(5):474-83, 2011.

Hovland, E. J. \& Block, R. M. Nonrecognition and subsequent endodontic treatment of dens invaginatus. J. Endod., 3(9):3602, 1977.

Hülsmann, M. Dens invaginatus: aetiology, classification, prevalence, diagnosis, and treatment considerations. Int. Endod. J., 30(2):7990, 1997. 
Jaya, R.; Mohan Kumar, R. S. \& Srinivasan, R. A rare case of dilated invaginated odontome with talon cusp in a permanent maxillary central incisor diagnosed by cone beam computed tomography. Imaging Sci. Dent., 43(3):209-13, 2013.

Kallianpur, S.; Sudheendra, U. S.; Kasetty, S. \& Joshi, P. Dens invaginatus (Type III B). J. Oral Maxillofac. Pathol., 16(2):262-5, 2012.

Kaneko, T.; Sakaue, H.; Okiji, T. \& Suda, H. Clinical management of dens invaginatus in a maxillary lateral incisor with the aid of conebeam computed tomography--a case report. Dent. Traumatol., 27(6):478-83, 2011.

Kaya-Büyükbayram, I.; Özalp, S..; Aytugar, E. \& Aydemir, S. Regenerative endodontic treatment of an infected immature dens invaginatus with the aid of cone-beam computed tomography. Case Rep. Dent., 2014:403045, 2014.

Kfir, A.; Telishevsky-Strauss, Y.; Leitner, A. \& Metzger, Z. The diagnosis and conservative treatment of a complex type 3 dens invaginatus using cone beam computed tomography (CBCT) and 3D plastic models. Int. Endod. J., 46(3):275-88, 2013.

Zubizarreta Macho, Á.; Ferreiro, A.; Rico-Romano, C.; AlonsoEzpeleta, L. Ó. \& Mena-Álvarez, J. Diagnosis and endodontic treatment of type II dens invaginatus by using cone-beam computed tomography and splint guides for cavity access: a case report. J. Am. Dent. Assoc., 146(4):266-70, 2015.

Matsusue, Y.; Yamamoto, K.; Inagake, K. \& Kirita, T. A dilated odontoma in the second molar region of the mandible. Open Dent. J., 5:150-3, 2011.

Mishra, S.; Mishra, L. \& Sahoo, S. R. A Type III dens invaginatus with unusual helical CT and histologic findings: a case report. J. Clin. Diagn. Res., 6(9):1606-9, 2012.

Muppa, R.; Nallanchakrava, H. S.; Mettu, S.; Dandu, R. V. \& Tadikonda, D. C. Type III B dens invaginatus: diagnostic and clinical considerations using 128-slice computed tomography. J. Indian Soc. Pedod. Prev. Dent., 32(4):342-5, 2014.

Narayana, P.; Hartwell, G. R.; Wallace, R. \& Nair, U. P. Endodontic clinical management of a dens invaginatus case by using a unique treatment approach: a case report. J. Endod., 38(8):1145-8, 2012.

Neves, F. S.; Bastos, L. C.; Almeida, M.S.; Bóscolo, N. F.; Haiter Neto, F. \& Campos, P. S. Dens invaginatus: A cone beam computed tomography case report. J. Health Sci. Inst., 28(3):24950, 2010. Nosrat, A. \& Schneider, S. C. Endodontic management of a maxillary lateral incisor with 4 root canals and a dens invaginatus tract. J. Endod., 41(7):1167-71, 2015.

Oehlers, F. A. Dens invaginatus (dilated composite odontome). Variations of the invagination process and associated anterior crown forms. Oral Surg. Oral Med. Oral Pathol., 10(11):1204-18, 1957.

Patel, S. The use of cone beam computed tomography in the conservative management of dens invaginatus: a case report. Int. Endod. J., 43(8):707-13, 2010.

Pradeep, K.; Charlie, M.; Kuttappa, M. A. \& Rao, P. K. Conservative management of type III dens in dente using cone beam computed tomography. J. Clin. Imaging Sci., 2:51, 2012.

Teixidó, M.; Abella, F.; Duran-Sindreu, F.; Moscoso, S. \& Roig, M. The use of cone-beam computed tomography in the preservation of pulp vitality in a maxillary canine with type 3 dens invaginatus and an associated periradicular lesion. J. Endod., 40(9):1501-4, 2014.

Tyndall, D. A. \& Rathore, S. Cone-beam CT diagnostic applications: caries, periodontal bone assessment, and endodontic applications. Dent. Clin. North Am., 52(4):825-41, 2008.

Vier-Pelisser, F. V.; Morgental, R. D.; Fritscher, G.; Ghisi, A. C.; Borba, M. G. \& Scarparo, R. K. Management of type III dens invaginatus in a mandibular premolar: a case report. Braz. Dent J., 25(1):738, 2014.

Vier-Pelisser, F. V.; Pelisser, A.; Recuero, L. C.; Só, M. V.; Borba, M.
G. \& Figueiredo, J. A. Use of cone beam computed tomography in the diagnosis, planning and follow up of a type III dens invaginatus case. Int. Endod. J., 45(2):198-208, 2012.

\section{Correspondence to:}

Eliana Dantas da Costa

Division of Oral Radiology

Department of Oral Diagnosis

Piracicaba Dental School

State University of Campinas

Campinas

BRAZIL

E-mail: edantasc@yahoo.com.br

Received: 29-08-2016

Accepted: 03-01-2017 